\title{
PARLIAMENTARY ELECTORAL LEGISLATION - LAW vis á vis JUSTNESS OF ELECTORAL LEGISLATION IN THE REPUBLIC OF CROATIA IN THE PAST 20 YEARS
}

\author{
Tomislav Dagen, PhD \\ Academy of Arts and Culture in Osijek \\ Ulica kralja Petra Svačića 1f, Osijek, Croatia \\ tdagen@net.hr
}

\author{
Marijana Majnarić, LLM \\ Constitutional Court of the Republic of Croatia \\ Trg Svetog Marka 4, Zagreb, Croatia \\ marijana_majnaric@usud.hr
}

\section{ABSTRACT}

In the last twenty years, through the democratic development of the Republic of Croatia, the problem of modernizing parliamentary electoral legislation and the need and desire to create a better and fairer electoral system as a whole, which will bring the Republic of Croatia into European integration and the map of Western democracies comes "to the surface". In order for the implementation of the political desire to join Western democracies and bring the Republic of Croatia closer to the European Union realize its full potential, the electoral system was changed in 1999, and since then seven elections have been held for the Croatian Parliament, and the Republic of Croatia has in the meantime become a full member of the European Union. On this democratic path and democratic-parliamentary progress of the Republic of Croatia, a constant and unchanged circumstance (parliamentary anomaly) was noticed, which the Constitutional Court warned about back in 2010, and that is the need to create a fairer electoral system, since these existing ones call into question legality and constitutionality of the election results (the warning which the Croatian Parliament still ignores). Therefore, in this paper, the authors, by analyzing the existing electoral system and comparing the 2000 and 2020 elections, identify its shortcomings, inconsistencies between the Act on Election of Representatives to the Croatian Parliament and the Act on Constituencies. Further analysis in this paper refers to the fact of imbalance in the number of voters in different constituencies in which an identical number of representatives is elected (malapportionment), and the lack of "justness" that allows issues of political engineering and forming post-election coalitions, as well as the possibility of representatives "entering" the Croatian Parliament with a minimum number of votes obtained. Also, the authors try to confirm the thesis that the existing electoral system of electing representatives to the Croatian Parliament as a legislative body of the Republic of Croatia 
needs to be made more just in order to completely fulfill its purpose of creating parliamentary democracy in accordance with the rule of law and the will of the people. In light of the above, the paper will compare and analyze the results of the aforementioned parliamentary elections and their shortcomings, and will provide an overview of the necessary changes and the creation of a future more just electoral system, which the Republic of Croatia certainly needs and which will reduce to a minimum the difference between law and justice in the procedures for the election of representatives to the Croatian Parliament.

Keywords: electoral system, justness, election of representatives, parliamentary elections

No political topic has been discussed so intensively in the Croatian public in the past thirty years as electoral systems.

Much of what is said and written is hard to call rational ${ }^{1}$

\section{INTRODUCTORY CONSIDERATIONS}

If Plato's politics can be interpreted as the interconnectedness of man, polis and universe, the contemporary legal-political vision of the ideal state should therefore be viewed through the prism of the true will of the people, which would be articulated by the electoral system and the election of people's representatives to public authorities. Precisely such articulation of the true will of the people through elected representatives in governing bodies, and in a concrete sense the legislative body, should be permeated not only by law - of the electoral legislation as such, but also by the principle/elements of justness that complements the true will and reflection of the voters. Therefore, Law and Justness, as two synonyms on which rests every desire of the people of a state to have a state that will be able to combine these two concepts, and we could in an utopian manner say two state-building ideals, in the modern understanding of Plato's ideal state ${ }^{2}$ should be condicio sine qua non of any parliamentary electoral legislation, and only then it could be said that there is a just and law-based electoral system that articulates the will of the people in the legislative body. The desire for the Ideal State will result in the fact that the Republic of Croatia, as a country with almost 30 years of democratic tradition of electing

Kasapović, M., Jesu li izborni sustavi sredstva dramatična utjecaja na sudbine zemalja? Političke analize, No. 32, 2017, pp. 17.

2 For more on the Ideal State, see Posavec, Z., Idealna država i mogućnost njena ozbiljenja- Studija o Platonovoj Državi i Kritiji, Politička misao, 1, Zagreb, 1978, Zagreb. 
people's representatives to the legislative authority ${ }^{3}$, should, given the nature of the democratic process and Western European democratic values, overcome and outgrow "childhood diseases", and with help of the parliamentary electoral system translate the true will of the voters through the representatives of the people into the legislative authority, i.e. into the mandates of the representatives in the Croatian Parliament. ${ }^{4}$ The desire to create and strengthen a modern democratic legal order in the postwar period in the Republic of Croatia, and to approach the true values of Western democracies, and thus the European Union, will include the process of modernizing electoral legislation, all with the aim of approximation and equalization of rights and justice. The modernization of electoral legislation, and perhaps the desire for a more just electoral system, will result in the adoption of a new Act on the Election of Representatives to the Croatian Parliament, which will be adopted by the House of Representatives at its session on October 29, 1999. ${ }^{5}$

Although two decades have passed since the adoption of the aforementioned act and seven parliamentary elections have been held for the election of members of the Croatian Parliament, the passage of time will raise the question of whether it has led to the development of justness of the electoral system in relation to the electoral system itself, which arises from positive legal provisions. Law and justness as syntagms of every electoral system, including the democratic electoral system in the Republic of Croatia, in the past two decades will undoubtedly be diametrically opposed poles that will detect both electoral anomalies and anomalies of direct election of people's representatives to the legislative body. Observed and detected electoral anomalies, in addition to the question of the justness of the electoral system, will raise the question of electoral democracy, the real purpose of the elec-

3 The thirty-year democratic tradition of electing people's representatives to the legislative body in the Republic of Croatia refers to the fact that the first multi-party elections for the Parliament of the then FR Croatia within the former SFR Yugoslavia were held in the first round on April 22, 1990 and in the second round on May 6, 1990, pursuant to the Decision on calling general elections at all levels in Croatia, which was adopted by the Presidency of the Central Committee-SKH on December 10, 1989. For more on the first multi-party elections, see Vukas, B., Jr., Hrvatska državnost-Pravnopovijesne prosudbe - uz 25. godišnjicu prijama Republike Hrvatske u Ujedinjene narode, Pravni fakultet Sveučilišta u Rijeci, Rijeka, 2018, pp. 142 and 143.

4 That there was a genuine will and desire to move closer to Western democratic values and traditions, including through the provisions of the new Constitution, the "Christmas Constitution" of the Republic of Croatia from 1990, can be seen in the statements of Vladimir Šeks in which he claims: "Another characteristic of the new Constitution is that it has all the characteristics of modern democratic acquis with all the consequences that follow from it. In this way, we have normatively and legally obtained a ticket for the European Community, and whether it will actually happen, that is another matter. However, we have legislatively adapted to joining the European Community." For more on this, see Šeks, V., Temelji hrvatske državnosti, Golden marketing/Tehnička knjiga, Zagreb, 2005, pp. 93 and 94.

5 Act on Election of Representatives to the Croatian Parliament, Official Gazette, No. 116/99. 
toral law as such, as well as the implementation of certain measures/warnings by the Constitutional Court, which again raises the question of law and justness of the parliamentary electoral legislation. Perhaps the best in this regard and following the introductory considerations of the author of this paper is the thought of Joseph LaPalombara, who states that "the Constitution provides a framework for democracy, but political parties and elections are its heart and soul." ${ }^{\circ}$ Precisely the elections as the "heart and soul" of any democracy should be based on justness, which will include, in addition to creating more just constituencies, the fact that the post-election coalition of parties is a fraud or a real reflection of the true will of voters. Although some authors believe that "there is no ideal electoral system, a system that will perfectly reflect the will of citizens and cover all the required factors, such as justness, regional representation, minority representation, etc.", as well as that the existing electoral system is the status quo which the main political actors avoid dealing with". ${ }^{7}$ Precisely because of this fact, the authors of this paper will, instead of political actors, deal with the true detection of the gap between law and justness in the process of electing members of the Croatian Parliament, and through a comparative method and method of analysis of election results and content analysis try to detect and identify weaknesses of the Croatian parliamentary electoral legislation, which is possibly despite the lege artis of the electoral process against the justness and Plato's Ideal State.

\section{ELECTORAL LAW AND PRINCIPLES OF ELECTORAL LAW}

In the early 1990s, the Republic of Croatia "experienced" its long-desired constitutional change that would enable it to gain independence, sovereignty and the ability to create a democratic and independent state in which power would come from the people and belong to the people as a community of free and equal citizens. ${ }^{8}$ One of the highest values of the constitutional order of the Republic of Croatia is a democratic multi-party system that is realized through national sovereignty and free elections. ${ }^{9}$ Thus, the political leadership of a country derives from

6 LaPalombara, J., and according to Deren-Antoljak, Š., Izbori i izborni sustavi, Društvena istraživanja, Zagreb, Vol. 1, No. 2 (2), 1992, pp. 215.

7 Pervan, M., Mehanički učinci izbornog sustava: slučaj izbornih jedinica u Hrvatskoj, Političke analize 9, No. 33-34, 2018, pp. 26-32, [https://hrcak.srce.hr/205958], Accessed 10 March 2021.

8 Article 1, paragraph 2 of the Constitution of the Republic of Croatia Official Gazette No. 56/90, $135 / 97,113 / 00,28 / 01,76 / 10$ and 5/14, hereinafter the Constitution.

9 The original foundations of the Constitution: "Respecting the free will of the Croatian people and all citizens in free elections, the Republic of Croatia is being shaped and developed as a sovereign and democratic state..."

Article 1, paragraph 3 of the Constitution states that the people exercise power through the election of their representatives and direct decision-making. 
free elections in which the voter exercises his or her active or passive suffrage. ${ }^{10} \mathrm{~A}$ competitive electoral system is a part of every democratic state that rests on the rule of law, whose foundation is characterized by the most important principles and values, among which stand out: universal suffrage, its equality, immediacy, secrecy and freedom of choice. Freedom of choice forms the very basis of democratic competitive elections, while immediacy means that the people are allowed to participate personally in the election of their representatives. Universal suffrage means that all voters have it, regardless of possible differences between them. ${ }^{11}$ The principle of secrecy means that the decision made by the voter on his or her vote must remain unknown to others. Last and most important in the context of this paper - the principle of equality of suffrage means that the legislator through the electoral system must ensure that the vote of each voter has equal value, i.e., that the weight of suffrage and the right to vote is equal. ${ }^{12}$ Consequently, every democratic society will seek to regulate and create an electoral system based on these fundamental principles, which will guarantee the conduct of competitive elections. This is because the real freedom of choice depends on the character and model of the electoral system through which citizens exercise state governance and through which representative democracy is achieved. ${ }^{13}$ Perhaps the best presentation of the relationship between the elections themselves and the effects they should have is also noticed by Deren-Antoljak in her article, who states; "Elections are not only the generally accepted (and only) legal basis for political power and the constitution of democratic political representation, but they provide more or less free communication between those in power and those governed, managers and followers, leaders and followers, representatives and the represented." ${ }^{14}$

These principles and preconditions are just some of the elements of Plato's Just State, because through them we repeatedly come to the essence, and that is whether the law and justness of elections and the electoral system are the true will of

10 The right to participate in elections as a candidate and to be elected as a representative of citizens in government is called passive suffrage. While active suffrage provides an answer to the question of who can elect government representatives, i.e., who has the right to vote.

11 Thus, in the Republic of Croatia, everyone has rights and freedoms, regardless of race, colour, sex, language, religion, political or other beliefs, national or social origin, property, birth, education, social status or other characteristics, Article 14, paragraph 1 of the Constitution.

12 As well, the Code of Good Practice in Electoral Matters of the Commission for Democracy and Law of the Council of Europe (hereinafter: the Venice Commission), adopted at the $51^{\text {st }}$ session on 5 and 6 July 2002, together with the reasoning adopted by the Commission at its $52^{\text {nd }}$ plenary session on 18 and 19 October 2002, in particular points 2, 2.1. and 2.2.

13 "Representative democracy is a system in which the government is formed by representatives of the majority, expressed in free and competitive elections..." Smerdel, B., Ustavno uredenje europske Hrvatske, Zagreb, 2013, pp. 5.

14 Deren-Antoljak, op. cit., note 6, pp. 220 and 221. 
the people, and if that does not happen or "the principle of justness is not implemented, then the state falls into a dangerous path of disorder that threatens its existence...." 15 Therefore, with an analytical and comparative approach, the authors will through this paper and research try to find out "what is the path of the Republic of Croatia?"

\section{PROPORTIONAL ELECTORAL SYSTEM AND ITS CHARACTERISTICS}

In the first ten years of Croatian electoral history or Croatian democracy, the main models of electoral systems changed: majority (1990), mixed (1992 and 1995) and proportional (2000). In 2000, the legislator in the Republic of Croatia opted for the introduction of a proportional electoral system ${ }^{16}$, which he considered to be the best guarantee of free and competitive elections. The basic proposal for the drafting of the new Act on the Election of Representatives to the Croatian National Parliament ${ }^{17}$ was the proposal of the Working Group for drafting the framework proposal and basic institutes of the Croatian election legislation from March 1999. ${ }^{18}$ In its proposal, the working group emphasized two basic principles: the principle of "fair political representation of all parts of the electorate, which includes fair parliamentary representation of political parties that express their interests and values", and the principle of effective political power, which should "prevent the creation of an atomized and polarized multi-party system in parliament, which jeopardizes political decision-making and implementation, encourages strong ideological polarizations and fundamentalizes conflicts in both parliament and society, and destabilizes the overall political order." ${ }^{19}$ With the enactment of the Act on the Election of Representatives to the Croatian Parliament in Croatia, a proportional electoral system was fully introduced in Croatia, electing 140 deputies in 10 constituencies. ${ }^{20}$ This act for the first time in the applica-

15 Posavec, op. cit., note 2, pp. 34.

16 "In majority of the existing democracies, proportional elections are applied." Nohlen, Dieter: Electoral Law and the Party System, Biblioteka alternative, Školska knjiga, Zagreb, 1992, pp. 32.

17 Act on Election of Representatives to the Croatian Parliament, Official Gazette, No. 116/99.

18 The members of that working group were professors Smiljko Sokol, Branko Smerdel, Mirjana Kasapović, Ivan Grdešić and Mario Jelušić.

19 Working group for drafting the framework proposal and basic institutes of the electoral legislation of the Republic of Croatia, Basic Principles and Institutes of the Act on the Election of Representatives to the Croatian National Parliament - Proposal, Zagreb, 1999.

20 With the reform of the electoral legislation after the adoption of the Act on the Election of Representatives to the Croatian National Parliament from 1999, Official Gazette, No. 116/99, the proportional electoral system was fully introduced in Croatia. The name Croatian National Parliament was introduced by the enactment of the Constitutional Act on Amendments to the Constitution, Official Gazette, No. 135/97. 
tion of the proportional electoral system divided the state territory into constituencies using the D'Hondt method in the election of all representatives, apart from the representatives of national minorities, and introduced an electoral threshold of $5 \%$. The same act also provided one constituency for all Croatian citizens residing outside Croatia in which up to 14 deputies are elected ( $11^{\text {th }}$ constituency) and the $12^{\text {th }}$ constituency consisting of the entire territory of Croatia for members of national minorities. The primary goal of dividing the territory into 10 constituencies was the regionalization of politics, namely, the goal was to elect local politicians who would represent the interests of their region. Since political parties highlighted candidates on their lists who did not come from the constituency in which they were elected, this goal was not fully met, and therefore in such an example we clearly notice differences in the implementation of the content of the right to justice and fairness of the electoral system. By opting for a proportional electoral system for the election of representatives to the Croatian Parliament, the legislator was guided by the fact that the Constitution prescribes that the system of representative government is a fundamental form of exercising people's sovereignty in which the Republic of Croatia is a multi-party parliamentary democratic state. The people, as a community of citizens, exercise power by electing their representatives on the basis of universal and equal suffrage. Therefore, the elected representative of the people is considered to be the representative of all citizens of the Republic of Croatia, not just the voters who elected him." 21 "He also applied the concept of so-called pre-reserved seats in such a way as to ensure that members of minorities have special representation in the national parliament, because minorities usually cannot elect their representatives in regular elections, and their election must be separated from the general electoral system. This is necessary in order to enable minorities, regardless of their number, to protect their minority interests in political decision-making processes and to participate in political power through their special representatives with the so-called positive discrimination." 22 The electoral system for the election of representatives to the Croatian Parliament is regulated by norms of a constitutional and legal nature, as well as norms of international law. We should also mention the norms that prescribe ethical rules of conduct and mutual relations of all participants in the election process. The mentioned electoral system as it was introduced in 2000 has remained in force today with minor changes, which occurred in 2014 and 2015 and are related to the mandatory introduction of the so-called women's quotas, (although it applies to both sexes). ${ }^{23}$ These changes also introduced the possibility of expressing one

\footnotetext{
21 Order of the Constitutional Court No. U-I-1203/1999 of 3 February 2000

22 Ibid. 18

23 The introduction of the women's quota did not have concrete results, i.e., the list can go to the elections regardless of the gender ratio, but if there are less than $40 \%$ of members of one sex, a fine is paid.
} 
preferential vote (closed unblocked lists), abolished the institute of list holders, banned the candidacy of persons who committed crimes, changed the regulation of election campaigns on public services and introduced the democratic use of more attention. in election observation. It can be concluded that these were only "cosmetic" changes, changes that approached European parliamentary/democratic values. These changes in their basis and content did not significantly affect the creation of an electoral system tailored to the needs of a modern democracy, which would be a real reflection of the true will of electors, voters and each individual, which would undoubtedly lead to full implementation of justice in articulating the will of voters and thereby the creation of a Just State.

\section{ACTUAL EFFECTS OF THE VALID ELECTORAL SYSTEM}

Electoral systems operate in complex political, economic, social and cultural environments, so their impact on political reality is not always easy to assess. However, in every society, they certainly have a great influence on democracy, the political and party system, but also on the notion of moral values. Perhaps in the wake of this we can cite the maxim or thinking of Denis F. Thompson by which he best depicts the meanings of the effects of the electoral system and the elections themselves; Elections can happen without democracy, but democracy cannot exist without elections". ${ }^{24}$ The very fact that democracy cannot exist without elections hides a great uncertainty between the border of law and the fairness of the same elections. When we talk about the influence of the electoral system on the political system, its two elements have the greatest influence on it: determining the results of elections and the constituency ${ }^{25}$. The system of determining the results of elections is a way of converting the votes of voters into the final result of the election, which includes the choice between the majority and proportional electoral system, the method of converting votes into seats and the election threshold. ${ }^{26}$ The Venice Commission, in its Code of Good Practice in Electoral Matters, emphasizes that the stability of the electoral law is crucial for the credibility of the electoral process, which in itself is essential in consolidating democracy. The Venice Commission points out that, in practice, the fundamental principles of the right to vote are not so much endangered as the stability of certain rules of the electoral law that

24 Thompson, F., D., Elections - creating a fair electoral process in the United States, The University of Chicago Press, 2002, pp. 1.

25 The basic elements of the electoral system are voting, running, constituencies and determining the results of elections.

26 Lijphart, A., points out that the choice between a majority and a proportional electoral system is one of two fundamental constitutional choices. The second choice is between the presidential and parliamentary system of government, Lijphart, A., Electoral Systems and Party Systems: A Study of Twenty-Seven Democracies, 1945-1990. Oxford, Oxford University Press, 1994, pp. 23. 
regulate the electoral system itself, including the determination of constituencies. Twenty years have passed since the beginning of the elections for the Croatian Parliament according to the proportional electoral system and ten years since the Constitutional Court of the Republic of Croatia (hereinafter: the Constitutional Court) in the Report ${ }^{27}$ on Unequal Voter Weight in Constituencies defined by Articles 2 to 11 of the Act on Constituencies for the Election of Representatives to the Croatian Parliament ("Official Gazette" No. 116/99) established that the constitutionality and legality of the division of territories into constituencies as in force could be called into question and called on the Croatian Parliament to "immediately" start the procedure of amending the boundaries of constituencies. The Constitutional Court thus pointed out that the division into constituencies introduced by the Act on Constituencies for the Election of Representatives to the Croatian Parliament ("Official Gazette" No. 169/99; hereinafter: the Constituency Act) produced an outcome in the number of voters per constituency which in all constituencies does not fit into the requirement of the Act on Election of Representatives to the Croatian Parliament ${ }^{28}$, according to whose provision from Article 39, paragraph 1, the number of voters in constituencies may not differ from $+-5 \%$. In addition to finding excessive discrepancies in the number of voters per constituency in the previous elections, the Constitutional Court found that this called into question the real equality of the right to vote, a principle expressed in Article 45 paragraph 1 of the Constitution ${ }^{29}$. Furthermore, he warned that another legal standard should be ensured, and that is maximum respect for the area of administrative-territorial units when determining the boundaries of constituencies. In conclusion, the Constitutional Court pointed out the necessity of immediate amendments to the Law on Constituencies, but also the need to determine the competent bodies in that law and prescribe the rules of the so-called the procedure of delimitation, i.e., the procedure of harmonization of areas and borders of constituencies. The Constitutional Court states that once certain constituencies are by nature subject to change. "It is especially important that the division into constituencies cannot be regulated once and for all. Migration processes require constant adjustment of constituencies to changed relations, by geographically changing the boundaries of constituencies, or by changing the number of

\footnotetext{
27 Order of the Constitutional Court No. U-X-6472/2010 of 8 December 2010, Official Gazette No. $142 / 10$.

28 Official Gazette No. 116/99, 109/00, 53/03, 167/03, 44/06, 19/07, 20/09, 145/10, 24/11, 93/11, $19 / 15,104 / 15,48 / 18$ and $98 / 19$.

29 Croatian citizens over the age of 18 (voters) have universal and equal suffrage in parliamentary, presidential and the European Parliament elections, and in the decision-making process in a state referendum, in accordance with the law.
} 
seats in a constituency." ${ }^{30}$ Changes in the number of voters in general constituencies, determined by the Act on Constituencies for the Election of Representatives, must therefore be constantly monitored. If necessary, their areas and borders must be periodically, in due time before the next parliamentary elections, adjusted to the actual situation of voters in them." One of the most important conclusions of the Constitutional Court is the following one:" Both the legality and the general democratic character of the overall elections depend on equal distribution of voters by general election units (on which distribution the equality of the weight of the electorate directly depends). Moreover, the assessment of the constitutionality of the entire election may depend on it: they would be unconstitutional if the excessive deviation in the number of voters in individual general constituencies would directly and indirectly affect the election result, i.e., if it would lead to different election results in a situation where all other elements of the electoral system would be or remain the same." Nevertheless, elections for the representatives of the Croatian Parliament are still conducted according to unchanged legal provisions, and the general democratic character of all elections may or may not remain a utopian expectation of the justness of the electoral system and possibly a just state.

\section{5. (IN)EQUALITY IN SUFFRAGE}

When dividing the territory of the Republic of Croatia into 10 constituencies, the problem is a very pronounced imbalance in the number of voters in different constituencies in which an identical number of deputies is elected, also known as malapportionment, which represents a "modern and refined way of violating the equality of suffrage as a constitutionalized principle that has found its place in a number of different international documents" 31 . Such "tailored" constituencies represent a shortcoming of the Croatian electoral system (unacceptable for democracy) when we talk about the negative effect - inequality in the strength of the right to vote, or a state in which one's vote is worth more than another. The basic aspiration in the organization of constituencies should be the equal influence of each vote with a more orderly division of the geographical space of the state. This is an issue that touches on the fundamental political rights of citizens guaranteed by the Constitution and their political equality, the changes of which are equally in the interest of both citizens and political parties. "It is considered to be a characteristic of a fair proportional electoral system that no one has significantly more mandates than they deserve according to what the citizens gave them in the

\footnotetext{
$30 \quad$ Nohlen, op. cit., note 16, pp. 48.

31 Palić, M., Učinci primjene razmjernog izbornog sustava u Republici Hrvatskoj, Zbornik radova Pravnog fakulteta u Splitu, 2012, Vol. 49, No. 1, pp. 49-58.
} 
elections." 32 Citizens have the right to vote in elections for "competing" candidates, but they also have the right (with a minimum of legitimate expectations) to fair and equitable representation from those to whom they have given (whom they felt they have given) their confidence.

Overview of the deviation of the number of voters from the allowed legal range of $+-5 \%$ in the parliamentary elections in 2000 and the last ones in $2020 . .^{33}$

\begin{tabular}{|l|c|c|}
\hline constituencies & $\begin{array}{c}\text { elections } \\
\mathbf{2 0 0 0}\end{array}$ & $\begin{array}{c}\text { elections } \\
\mathbf{2 0 2 0}\end{array}$ \\
\hline I. & $-1,41$ & $-6,20$ \\
\hline II. & 4.49 & 6,45 \\
\hline III. & $-0,96$ & $-4,65$ \\
\hline IV. & $-9,47$ & $-14,21$ \\
\hline V. & 3,39 & $-7,43$ \\
\hline VI. & $-6,17$ & $-9,85$ \\
\hline VII. & 1,03 & 12,05 \\
\hline VIII. & 1,76 & 2,25 \\
\hline IX. & 1,01 & 12,49 \\
\hline X. & 6,33 & 9,09 \\
\hline average & 3,60 & 8,47 \\
\hline range & 15,80 & 26,70 \\
\hline
\end{tabular}

From the attached table, and in terms of proving the thesis in this paper and the research, it is evident that in the 2000 elections there were units that "jumped" outside the legally allowed range $+/-5 \%-2000$ three, and in 2020 it is as many as eight out of ten constituencies. Also, over time, the average deviation of other units increases, from $3.6 \%$ in 2000 to 8.47 in 2020 . At the same time, the difference between the smallest and the largest constituency is growing, calculated at the level of one mandate, which means, for example, that in 2020 in the IV. constituency 22328 voters elected one representative, while in IX the electoral unit of one representative was elected by 29,277 voters. One constituency, VII remained within the legal framework, and three constituencies (IV, VI and X) were outside

32 prof. Podolnjak, 10 December 2018 at the Citizen's Initiative forum The People Decide: Does power belong to the people and who steals our referendum?

33 Shaded - constituencies that deviate outside the legal framework of $+1-5 \%$, average - average percentage deviation (absolute values) of all constituencies range - range between the maximum negative and maximum positive deviation in each year (or the difference between the least numerous and most numerous constituencies units expressed as a percentage of the average constituency). Čular, G., Hoce li sljedeci parlamentarni izbori biti neustavni? Fakultet političkih znanosti u Zagrebu, September, 2020, pp. 5, 6 and 7 [https://www.gong.hr/media/uploads/20200914_izborne_jedinice.pdf], Accessed 10 March 2021. 
the legal range. It is noticeable that the deviations usually increased over time, so that the small number of constituencies became smaller in number of voters, and the overnumbered ones received more and more voters. This fact supports the thesis that the main cause of inequality of constituencies with regard to the number of voters is most likely demographic trends. However, this fact has an impact on the inequality in the weight of the vote, where voters of the same units are always "overrepresented" and others are always "underrepresented", which turns individual inequality of suffrage into regional inequality. The aforementioned speaks in favor of the thesis about the eternal "conflict" of law and justness of the electoral system and legislation in the Republic of Croatia.

Furthermore, in terms of further proving and reviewing the relationship between the law and justness of the electoral system and legislation in the Republic of Croatia, in support of proving Jelušićs allegations should be cited in which he states, "although when creating this electoral system in 1999, some members of the commission for drafting the basic principles of then a new electoral system in Croatia thought that due to the the stability of the executive power of the Croatian Parliament thus formed, it would be good if a dozen deputies were still elected by a relative majority system. Such a model is simpler and, with the current electoral threshold rate of 5\%, ensures satisfactory stability of the government resulting from the Croatian Parliament. Although the majority systems institutionally generate a stable executive power with less pronounced representativeness and democracy, this proportional electoral model has so far become established in our country, becoming an important part of the Croatian political system and political culture and generally accepted by most key political parties and the public. In addition to a possible increase in the number of possible preferential votes, the only urgent change in the electoral system is the correction of the territories of individual constituencies so that due to demographic changes in the past two decades they are all reduced to the proportions prescribed by the Croatian Parliament in the number of voters in some of them in the amount of $+/-0.5 \%$." 34

\section{FREE AND JUST (FAIR) ELECTIONS}

Almost 30 years ago, in the beginnings of independence, when the process of democratization in the Republic of Croatia was starting, we pointed out the following: "Political parties and movements guarantee with their own position that no one should fear democracy or to live in democracy in fear; no one has reason to fear free democratic elections. Democracy is freedom - the rights and fundamental

34 Jelušić, M., judge of the Constitutional Court of the Republic of Croatia, Interview of the author, February 2021. 
victory of every man and of all people. All parties and movements, together and individually, must be a support to every man and all people in the exercise of their political and social rights, in the preservation of their freedom and human rights. Therefore, it is the duty of all parties and movements to protect every person, regardless of which party or movement he or she belongs to. ${ }^{35}$ Subsequently, the Declaration on Criteria for Free and Fair Elections ${ }^{36}$ was adopted, stating that elections are a necessary and unavoidable element of sustainable efforts to protect the rights and interests of those governed and that everyone has the right to participate in them as a key factor, all with the aim of exercising human rights and freedoms. The fundamental principle is "free and fair election", which means that in any state the authority of the government can only come from the will of the people, which is expressed in fair, free and fair elections held at regular intervals, on the basis of universal, equal and secret voting right. Each voter has the right to exercise his right to vote as well as others, and his vote must have the same weight as the votes of all others. In the context of the law and responsibilities of the states, it is emphasized that the states should take the necessary legislative and other measures in accordance with their constitutional procedure, in order to guarantee the rights and institutional framework for regular, fair, free and fair elections. Taking into account the last 20 years of our electoral system and the statements mentioned in points 4 and 5, we cannot escape the impression that these principles and postulates have been somehow neglected, anachronized due to the political interests of certain groups, thus repeatedly and unequivocally the question of justness in relation to the law of the electoral system.

\section{AUTHORITY WITHIN THE LIMITS OF LAW AND ITS JUSTNESS}

As early as the $12^{\text {th }}$ century in England it was believed that a ruler must obey God and the laws he had enacted at the time. This obligation of the ruler was confirmed by the Grand Charter of Liberties (Magna Charta Libertatum) of 1215, which established the ruler's obligations to the earthly barons and recognized their right to rebel if these obligations were violated. If we start from the fact that the goal of politicians and politics is the common good, then it should be said that the precondition for the common good is justness as the highest virtue of the individual which ultimately leads to a just community ${ }^{37}$ (state) of all. Authorities are expected to pass laws that will ensure the justice of democracy. The idea underlying

\footnotetext{
35 Declaration of the Principle of Conduct for Election Participants, Official Gazette No. 13/90 od 30 March 1990.

36 Unanimously adopted by the Interparliamentary Council, 154 th session, Paris, 26 March 1994.

37 Plato defines justness as the virtue of the individual. Aristotle interpreted justness as equality.
} 
proportional representation is that each party in the representative body should be represented in proportion to the part of the electorate that supported it in the elections. In legal theory, one of the characteristics of proportional representation is most often its justness. ${ }^{38}$ "The definition of the law is: the law is a normative act of the state, a regulation of the highest legal force after the Constitution. The law formulates the people's representation or the people directly. The law is aimed at implementation. All regulations and all actions must be in accordance with the Constitution, legislation and law, as prescribed by Article 5 of the Constitution." ${ }^{39}$ According to Smerdel, new categories of legislation have been created in our country, and one of them consists of the laws that are applied, although in some way declared unconstitutional, but still continue to be applied until some point in the future. As a result, legal uncertainty arises, ${ }^{40}$ and any reflection outside the literal grammatical interpretation of regulations becomes dangerous, especially if it has to do with politics, which is inevitable in constitutional matters (which includes the electoral system). Such a fact creates political chaos, legal inequality and destabilization of society itself as a body of every state. In this sense, we should also mention Fuller's reflections, which state that certain moral standards - "principles of legality" are built into the very concept of law, so that nothing is valid if the law does not meet those standards. Based on these principles of legality, ${ }^{41}$ there is an internal morality according to the law that imposes a minimum morality of justice. The principles of legality together guarantee that each law will embody certain moral standards of respect, fairness and predictability that represent important aspects of the rule of law. Democracy has a chance to develop only with the help and joint action of an enlightened leadership and an active people, which is not possible without confidence in the justice of the system. Therefore, the above definitions and assumptions of democracy and justice according to Fuller in

38 However, from the point of view of voters (citizens), the connection between the given votes and the election results is not very transparent. The elections are dominated by political parties, i.e., the lists of candidates they determine. Therefore, voters do not know the proposed candidates at all, so they vote in the elections according to the preferences of a particular political party. Changes to the electoral system have tried to circumvent this by introducing preferential voting, which "gives importance" to the will of the voters themselves.

39 Branko Smerdel's book Ustavno uredenje europske Hrvatske, II. izmijenjeno i dopunjeno izdanje, 2020 was published by Narodne novine d.d.

40 According to the former President of the Constitutional Court, Dr. sc. Jasna Omejec, the legal system has been turned into a "patch" of unclear and contradictory solutions and new institutions foreign to the Croatian tradition." Ibid. 38, p. 552.

41 "Legal rules must meet 8 minimum requirements in order to be counted as a real law. The rules must be: 1 . sufficiently general, 2 . publicly announced, 3 . applicable to future conduct, 4 . minimally clear and comprehensible, 5 . non-contradictory, 6 . relatively constant, 7 . must be obedient and 8 . must be applied in a way that does not differ from the obvious meaning", Fuller, L., The Morality fo Law, Yale University Press, New Haven and London, 1964. 
the Croatian context remain in contradiction with the existing electoral legislation and electoral system.

\subsection{Representative mandate, pre and (post)election coalitions as a result of injust representation}

The "recipe" for overcoming chaos and hopelessness is to create civilized communities from local, national to supranational. The realization of the above is not possible without professional, intelligent and ethical interpretations of the existing legislative framework which will both shape the rules of conduct and persist in their just and reasonable application. "In other words, the current institutions ${ }^{42}$ need to be "reset", ${ }^{43}$ especially through the filter of morality, ${ }^{44}$ legitimacy ${ }^{45}$ and legality." 46 We are facing a situation of deep democratic crisis marked by declining citizen engagement caused by a deficit of values, faith in procedure, law and the Constitution. According to Lauc, legitimacy should be thought of as a bridge between morality and legality. Its raison d'etre is the expression of belief in certain types of government by citizens. However, the lack of politically responsible behaviour, morals, honesty (justice), led to the fact that this model of political relations was spent. ${ }^{47}$ The future of political life should begin to be created outside the framework of general politicization, populism and anti-intellectual atmosphere with the right measure and optimal model that will ensure moral defensibility (good-evil), legal effectiveness and political feasibility of any regulation. State activities must not be arbitrary, but based on predetermined rules of the game, le-

42 "It should always be borne in mind that institutions are concrete people. Therefore, their motivation, morality and ethics, training (knowledge and skills), teamwork, social sensitivity are essential for fulfilling the content and procedures of decision-making and action. The resilience of democracy is inherently linked to the healing of its institutions - vital components that protect the rights of those in the minority and contribute to resolving political disagreements in a peaceful, orderly manner. This is a prerequisite for the realization of economic efficiency, political freedom and social security". Lauc, Z., MORALITET - LEGITIMITET - LEGALITET = Trojstvo konstitucionalnog inženjeringa, HAZU 30-godišnjica Ustava RH (1990-2020); Ustavne promjene i političke nagodbe - Republika Hrvatska izmedu ustavne demokracije i populizma, HAZU, Zagreb, 2020 pp. 36.

43 One should unlearn what has been learned, unlearn the fact that "vocation" is valued instead of knowledge.

44 "This is because morality (honesty) is the most important category for economic and political prosperity". Ibid. 38, pp. 10.

45 The notion of legitimacy implies the dignity of a political order to be recognized, Habermas, J., Problemi legitimacije u modernoj državi, Gledište, 1979, pp. 135.

46 Ibid. 38, pp. 4.

47 Josipović, I., "The Croatian electoral system is unfair and undemocratic. There is no democracy in the parties. The electoral system supports the selection of cats from the political sacks." [https://www. jutarnji.hr/vijesti/hrvatska/josipovic-se-obratio-hrvatskoj-javnosti-zelim-vam-odgovoriti-na-dva-vazna-pitanja-462136], Accessed 15 March 2021. 
gitimized by the people invited to participate in the adoption of these rules ${ }^{48}$ in a specific case, by the people called to decide who will represent them as a justly elected representative in parliament. ${ }^{49}$ Following this thinking, we can take the research conducted by Guy S. Goodwin-Gill, who states:... electoral obligations and the goal of representative democracy have a program dimension, predicting progress in building a democratic institution, strengthening people's confidence in the democratic process and leading to better and more democratic governments." 50

However, contrary to the above, the parliamentary elections held in 2020 show all the "luxury and political colour" of the representation of the people by (unwanted) representatives. The most common situation is that the representatives who received the mandate is replaced by another representative, i.e., his mandate is "handed over" to another representative. Such true and conscious cheating of voters and manipulation of the electoral system is the modus operandi of all political options, especially the current ruling nomenclature, because the lists include "strong and resounding" candidates who cannot enter the Croatian Parliament by Law $^{51}$ (e.g., ministers, state secretaries, prefects, members of the management board of companies, etc. $)^{52}$ or who are expected to be ministers in case of victory of a certain political option. Furthermore, as an electoral anomaly in Croatian political everyday life, which refers to the deliberate manipulation of justice and the will of voters, and in connection with the election procedure in Croatia, we have the case of positions of Marko Milanović Litre, who entered the Parliament as a replacement for MEP Ruža Tomašić. The mentioned representative of the Croatian Conservative Party was on the list of the Homeland Movement in the $10^{\text {th }}$ constituency, but as she remains in the European Parliament, Milanović Litre entered the

48 Rule of law.

49 European Court of Human Rights, in the case of Yumak and Sadak against Turkey, Judgment no. 10226/03 of 8 July 2008 stated that: "States Parties to the Convention are obliged to hold elections that ensure the expression of the will of the people, while respecting the right of the individual citizen to vote and to stand for election. Any restrictions imposed by electoral legislation must not impede the free expression of the will of the people in the election of the legislature - in other words they must reflect... the effort to maintain the integrity and effectiveness of the electoral process aimed at recognizing the will of the people through universal suffrage.", point 109, Order of the Constitutional Court No.: U-I-4780/14 of 24 September 2015.

50 Goodwin-Gill, Guy S., Free and Fair Elections, Inter-Parliamentary Union, Geneva, 2006, pp. 71, [http://archive.ipu.org/PDF/publications/Free\&Fair06-e.pdf], Accessed 15 March 2021.

51 Article 9 paragraph 1 of the Act on the Election of Representatives to the Croatian Parliament.

52 Thus, instead of those to whom they gave a preferential vote such as: Andrej Plenković, Nina Obuljen Koržinek, Zvonko Milas, Gordan Grlić Radman, Darko Horvat, Ivan Anušić, Josip Škorić, Zoran Đuroković, Zdravko Marić, Mario Banožić, Josip Aladrović, Danijel Marušić, Davor Božinović, Tomo Medved, Tomislav Ćorić, Oleg Butković, Ivan Malenica, Nediljko Dujić, Luka Brčić, Božidar Kalmeta, Marijan Kustić, Vili Beroš, Blaženko Boban, Andro Krstulović Opara, Ante Mihanović, Predrag Fred Matića Zlatko Komadina, Damir Bajs, Željko Kolar and Matija Posavac - the voters will be represented by "second-league players" they did not elect. 
Parliament instead of her, thus "expelling" Robert Pauletić, although he won only 19 preferential votes $(0.09$ percent of the total number of votes achieved by that list). At the same time, Pauletić, as the candidate of the Homeland Movement, won 3,907 votes, or $19.79 \%$ of the total number of votes achieved by the entire list. If Tomašić, Milanović Litre and Pauletić were candidates on the candidate list of one party, then Pauletić would enter the Parliament. The law ${ }^{53}$ says that on the list of one party the elected representative is replaced by an unelected candidate, in which case he is elected according to the preferential votes won, and if there is no candidate on the list to replace the representative, then he is determined by the party proposing the list. A candidate who enters by preferential votes should win at least 10 percent of the preferential votes in relation to the number of votes won by the list on which he is running. In the case of candidate lists of two or more parties, as is the case here, the elected representative shall be replaced by an unelected candidate "from the same party to which the representative whose term of office ended or stands belonged at the time of the election". In that case, too, preferential votes are seen first, and if on the list "there is no candidate to replace the representative, then the deputy is appointed by the political party to which, at the time of the election, the representative whose mandate ended belonged". According to the legal provisions, Milanović Litre, as the only remaining representative of the Croatian Conservative Party on the list, would have replaced Ruža Tomašić even if he had not won a single preferential vote. In this way, people who do not represent the true voting will of the voters and who received a minority of votes enter the Parliament, which can repeatedly lead to the conclusion that this is voter fraud and a legal anomaly, which, despite the fact that everything is in accordance with existing regulations is not in accordance with the principle of justness. Pauletić defended his rights with a constitutional complaint, but unsuccessfully, it was rejected with the explanation that: "in a situation when a candidate from the same list and a member of the same political party as the elected candidate is appointed as a deputy, the number of preferential votes of the applicant, who is a member of another political party, is not decisive." ${ }^{54}$ Therefore, one could talk about the partial composition of the Parliament without being based on the real will of the voters, ${ }^{55}$ which was certainly not the intention of the legislator when he introduced preferential voting in our electoral system. On the contrary, it was then defended by the fact that the voters choose the candidates of their choice

\footnotetext{
53 Article 42 of the Act on the Election of Representatives.

54 Decision of the Constitutional Court No. U-III-3786/2020 of 23 February 2021.

55 "The elected representative of the people is considered to be the representative of all citizens of the Republic of Croatia and not only the voters who elected him. Such representative rule is expressed through a representative mandate derived from the theory of indivisible people's sovereignty.", Decision of the Constitutional Court No. U-I-3789/2003 of 8 December 2010.
} 
over other candidates on the same list, while political influence is largely transferred from political parties to the benefit of citizens. The intention was to give citizens the opportunity to influence the composition of the representative body, by choosing those who managed to motivate them with their work or program and gain their trust. The legislator believed that in this way the will of those who compiled the lists would not be decisive and that the political scene would be enriched by people who would actively and responsibly approach the role of candidates, and then representatives. However, we can conclude that this intention of the legislator, due to the "acrobatics" of politicians and the desire for "power" of the newly elected representatives deprived of any sense of legitimacy and justness of this "power", failed to fully materialize. In this example (which is not the only one of this kind) we can speak in its entirety about falling on the test of democracy and justness of all intentions of the legislator related to the "democratization" of the electoral system and "playing" the role of voters in it, and we can say that with the accession of the Republic of Croatia to the European Union such a practice has not changed. Thus, the division of territories into constituencies was aimed at electing local politicians who will represent the interests of the voters of their region in the Parliament, however, this goal was not fully met either. An example of this is the previously mentioned case of Milanovic Litre who, as a citizen of Zagreb, will represent voters from the $10^{\text {th }}$ constituency, while it will not be the actual "representative of those voters, Pauletić. ${ }^{6}$ Furthermore, if we recall that the idea on which proportional representation rests is that each party in the representative body is represented in proportion to that part of the electorate which supported it in the elections, and that the principle of justice is thus achieved, we cannot fail to notice implementation of that content with representatives entering Parliament in the manner set out above. All this represents a "violation" of the essential postulates on which the election of members of Parliament is based, and at the same time fully confirms Smerdel's claim that any reflection outside the literal grammatical interpretation of regulations becomes dangerous (the authors would say in vain) is fully realized, until the beginnings of efforts to achieve more just voter representation are seen.

In the further presentation of the Croatian electoral system and the presentation of the lack or absence of justness in respecting the will of the voters, we can observe the example of pre-election and post-election coalitions. "In political relations, the

56 Ruža Tomašić does not see anything disputable in the fact that now the citizen of Zagreb will represent the south of Croatia in the Parliament, [https://www.jutarnji.hr/izbori/vijesti/umjesto-ruze-tomasic-u-sabor-ide-njezin-asistent-koji-je-dobio-19 preferencijalnih-glasova-15006885], Accessed 15 March 2021. 
term coalition refers to an alliance $e^{57}$ of political parties formed before or after the parliamentary elections, usually in parliamentary democratic systems, usually with the aim of making it easier for the coalition members to exercise power in order to create political preconditions for increasing political profits and jointly achieving certain political goals" ${ }^{58}$ In Croatian legal and political history, it was the Government of Democratic Unity aimed at preserving national interests caused by the state of war. ${ }^{59}$ That coalition would pass the so-called proportionality test, it was necessary in a democratic society and its work (existence) justified its formation. However, in recent legal and political history, we have witnessed how some political parties go to the polls on their own, although they are aware that after the end of the elections, and in accordance with the mandates won, they will not be able to participate in government. Therefore, they very skillfully form post-election coalitions and offer "their services" to the winning majority. These are post-election coalitions that are not banned, moreover, they are legitimate, especially if such "small" parties within the government succeed in realizing the promised programs useful for society and the state. The political scene in Croatia was shaken for the first time in history because a political party elected on the list of opposition political parties moved into a coalition with the ideologically opposed ruling party (we are talking about the Croatian People's Party and its coalition with the Croatian Democratic Union and its entry to the Government). ${ }^{60}$ According to Kasapović, when creating coalitions, "it is recommended to respect the principle of electoral responsiveness, according to which parties that have suffered a drop in voter support compared to the previous elections should not participate in the new coalition government." The aforementioned coalition is also specific because the leadership of the Croatian People's Party based its election campaign, among other things, on the fact that it would never enter into agreements or a coalition with the

57 Pre-election alliances are formed between political parties that believe that, as a coalition, they will synergistically achieve greater political gain (more votes) among voters than they would achieve in the elections alone, for their programs and candidates who are elected. The post-election coalition is aimed at creating a parliamentary majority that forms a joint coalition government in order to achieve the common interests and goals of the parties that joined the coalition. Arlović, M., Vlada demokratskog jedinstva koalicijski odgovor na velikosrpsku agresiju, Zbornik radova Pravnog fakulteta u Splitu, Vol. 57 , No. 2, 2020, pp. 454.

58 Ibid.

59 Or as the public likes to say war government.

60 Examples: Both the mighty Christian Democratic and Christian Social Union of Germany entered into coalitions with ideologically completely opposite Social Democrats (and did not announce this before the election!) because there was no other choice. It was similar in Austria when the liberal 'Freelancers' once formed a coalition with the People, which greatly excited the EU. Greek left-wing Syriza is in a coalition with the far-right 'Independent Greeks', although they are ideologically on completely opposite sides, [https://croexpress.eu/pogled-iz-iseljenistva-koalicija-hdz-a-i-hns-a-nije-prevara-glasaca/], Accessed 15 March 2021. 
Croatian Democratic Union, however, this eventually happened. In addition, the Croatian People's Party, as the opposition, initiated a no-confidence vote in some ministers, called the government the "Titanic government" and called new elections, and then in June 2020 supported the unstable government of the Croatian Democratic Union and gained "power" over the two ministries. That the Croatian People's Party, as one of the longest-running political parties, has lost its credibility is shown by only one mandate won in the 2020 parliamentary elections. Thus, the Croatian People's Party somehow became a "Titanic party", on the verge of slipping off the national political scene. There were debates in the general public about whether this type of coalition could be considered a "fraud" of voters, or was such a coalition of national interest in the sense that there would be no new elections and political instability in the country? We have already concluded that such coalitions are allowed and that they are common in other countries as well. However, an ordinary voter (citizen) who has given his vote to a certain political option, and it then inclines to a possibly undesirable option (combination) can lead to a weakening of the trust and legitimacy of the elected, as well as to the political system of a country.

\section{CONCLUDING REMARKS}

Precisely on the trail of modern constitutionalism based on the idea of a sovereign people that has the ultimate power to institutionalize power in elections and parliament and other constitutional forms, we question whether all of the above is just $^{61}$ in relation to voters-citizens (people)? John Rawls states that "every person possesses inviolability based on a sense of justness which society, even if it is called a welfare or liberal society, cannot overcome through its institutions." ${ }^{62}$ If justness is understood as the crown of all virtues, then it is not and cannot be the subject political bargaining or calculations of social institutions due to some social interest. "Understanding justness as the first virtue of social institutions reveals to us the importance of modern institutions of the basic structure of liberal constitutional democracy as the most important generators and distributors of justice." 63 In a political community where there is no practical agreement on the (political) conception of justness, ${ }^{64}$ lacks the necessary basis for the community as a whole.

${ }^{61}$ The HDZ election program in the 2016 parliamentary elections was entitled "Economic Growth, New Jobs and Social Justice Program.” [http://moj.hdz.hr/sites/default/files/hdz_program_gospodarski_rast_nova_radna_mjesta_i_drustvena_pravednost.pdf], Accessed 15 March 2021.

62 Rawls, J., A Theory of Justice, Revised Edition, 1971, pp. 105.

63 Berdica, J., Pravednost kao prva vrlina društvenih institucija, Pravni fakultet u Osijeku, 2013, pp. 1.

64 "The political conception of justness is independent, but it is not self-sufficient, it is the citizens who are called to complete it." Ibid. 62, pp. 674. 
The political conception of justice is independent, but it is not self-sufficient, it is the citizens who are called to complete it. Taking into account the way our politicians act, we come to the conclusion that this action certainly lacks justnesspolitical justness, but also political values. Justness and political values, on which modern parliamentary democracy rests, have largely remained within the same framework as twenty years ago in the Republic of Croatia, and with the entry and gaining full membership in the European Union, such values have not been set as primary and decisive in the context of parliamentary election legislation. It is precisely the lack of the above that will affect the lack of moral identity and loyalty to the people who face the failure of great pre-election and post-election promises almost every day. Therefore, perhaps it is time for justness to remain in our political life as a fundamental virtue, as a starting point from which we can develop political relations and society in general, and thus try to create in some elements Plato's Just State.

\section{REFERENCES}

\section{BOOK AND ARTICLES}

1. Arlović, M., Vlada demokratskog jedinstva koalicijski odgovor na velikosrpsku agresiju, Zbornik radova Pravnog fakulteta u Splitu, Vol. 57, No. 2, Split, 2020

2. Berdica, J., Pravednost kao prva vrlina društvenih institucija, Pravni fakultet u Osijeku, Original article, Osijek, 2013

3. Čular, G., Hoće li sljedeći parlamentarni izbori biti neustavni?., Fakultet političkih znanosti u Zagrebu, Zagreb, 2020

4. Fuller, L., The Morality fo Law, Yale University Press, New Haven and London, 1964

5. Habermas, J., Problemi legitimacije u modernoj državi, Gledište, 1979

6. Goodwin-Gill, Guy S., Free and Fair Elections, Inter-Parliamentary Union, Geneva, 2006

7. La Palombara, J., a prema Deren-Antoljak, Š., Izbori i izborni sustavi, Društvena istraživanja, Zagreb, 1992

8. Lauc, Z., MORALITET - LEGITIMITET - LEGALITET = Trojstvo konstitucionalnog inženjeringa, HAZU 30-godišnjica Ustava RH (1990-2020); Ustavne promjene i političke nagodbe - Republika Hrvatska izmedu ustavne demokracije i populizma, HAZU, Zagreb, 2020

9. Kasapović, M., Jesu li izborni sustavi sredstva dramatična utjecaja na sudbine zemalja?, Političke analize, No. 32, 2017

10. Lijphart, A., Electoral Systems and Party Systems: A Study of Twenty-Seven Democracies, 19451990. Oxford, Oxford University Press, 1994

11. Nohlen, D., Izborno pravo i stranački sustav, Biblioteka alternative, Školska knjiga, Zagreb, 1992

12. Palić, M., Učinci primjene razmjernog izbornog sustava u Republici Hrvatskoj, Zbornik radova Pravnog fakulteta u Splitu, Vol. 49, No. 1, 2012 
13. Pervan, M., Mehanički učinci izbornog sustava: slučaj izbornih jedinica u Hrvatskoj, Političke analize 9, 2018

14. Posavec, Z.: Idealna država i mogućnost njena ozbiljenja-Studija o Platonovoj Državi i Kritiji, Politička misao, Zagreb, 1978

15. Rawls, J., A Theory of Justice, Revised Edition, 1971

16. Smerdel, B., Ustavno uredenje europske Hrvatske, II. izmijenjeno i dopunjeno izdanje, Official Gazette, 2020

17. Thompson, F., D., Elections - creating a fair electoral process in the United States, The University of Chicago Press, 2002

18. Šeks, V., Temelji hrvatske državnosti, Golden marketing/Tehnička knjiga, Zagreb, 2005

19. Vukas, B., ml., Hrvatska državnost - Pravnopovijesne prosudbe - uz 25. godišnjicu prijama Republike Hrvatske u Ujedinjene narode, Pravni fakultet Sveučilišta u Rijeci, Rijeka, 2018

20. Šeks, V., Temelji hrvatske državnosti, Golden marketing/Tehnička knjiga, Zagreb, 2005

\section{ECHR}

1. Case of the European Court for Human Rights, Yumak and Sadak against Turkey, Judgment No. $10226 / 03$ of 8 July 2008

\section{EU LAW}

1. Code of Good Practice in Electoral Matters of the Commission for Democracy and Law of the Council of Europe, the Venice Commission, 2002

2. Declaration on Criteria for Free and Fair Elections, Interparliamentary Council, $154^{\text {th }}$ Session, Paris, 1994

\section{LIST OF NATIONAL REGULATIONS, ACTS AND COURT DECISIONS}

1. Constitution of the Republic of Croatia, Official Gazette, No. 56/90, 135/97, 113/00, $28 / 01,76 / 10$ and $5 / 14$

2. Act on Election of Representatives to the Croatian National Parliament, Official Gazette, No. 116/99 of the Act on Election of Representatives to the Croatian Parliament, Official Gazette No. 116/99, 109/00, 53/03, 167/03, 44/06, 19/07, 20/09, 145/10, 24/11, 93/11, $19 / 15,104 / 15,48 / 18$ and $98 / 19$

3. Basic Principles and Institutes of the Law on the Election of Representatives to the Croatian National Parliament - Proposal, Zagreb, 1999

4. Order of the Constitutional Court No.: U-I-1203/1999 of 3 February 2000

5. Order of the Constitutional Court No: U-I-4780/14 of 24 September 2015

6. Report of the Constitutional Court No: U-X-6472/2010 of 8 December 2010

7. Decision of the Constitutional Court No: U-III-3786/2020 of 23 February 2021

8. Order of the Constitutional Court No. U-I-3789/2003 of 8 December 2010

9. Declaration on the Principles of Conduct of Election Representatives, Official Gazette No. $13 / 90,1990$ 
10. Interview with Mario Jelušić, judge of the Constitutional Court of the Republic of Croatia, Interview of the author, Constitutional Court, Zagreb, February 2021

\section{WEBSITE REFERENCES}

1. [https://hrcak.srce.hr/205958], Accessed 10 March 2021

2. [https://www.gong.hr/media/uploads/20200914_izborne_jedinice.pdf], Accessed 10 March 2021

3. [https://www.jutarnji.hr/vijesti/hrvatska/josipovic-se-obratio-hrvatskoj-javnosti-zelim-vamodgovoriti-na-dva-vazna-pitanja-462136 2], Accessed 15 March 2021

4. [https://www.jutarnji.hr/izbori/vijesti/umjesto-ruze-tomasic-u-sabor-ide-njezin-asistentkoji-je-dobio-19 preferencijalnih-glasova-15006885 7], Accessed 15 March 2021

5. [https://croexpress.eu/pogled-iz-iseljenistva-koalicija-hdz-a-i-hns-a-nije-prevara-glasaca/], Accessed 15 March 2021

6. [http://archive.ipu.org/PDF/publications/Free\&Fair06-e.pdf], Accessed 15 March 2021

7. [http://moj.hdz.hr/sites/default/files/hdz_program_gospodarski_rast_nova_radna_ mjesta_i_drustvena_pravednost.pdf], Accessed 15 March 2021 